\title{
KONSEP MANUSIA BARU BERDASARKAN PERSPEKTIF PAULUS \\ DALAM EFESUS 4:17-32 DAN IMPLEMENTASINYA DALAM KEHIDUPAN ORANG PERCAYA
}

\author{
Darius $^{1}$ \\ sttjaffraymakassar@yahoo.co.id \\ Robi Panggarra \\ robipanggarra@yahoo.co.id
}

\begin{abstract}
ABSTRAK
Tujuan dalam penulisan karya ilmiah ini adalah: Pertama, menjelaskan konsep biblika mengenai manusia baru dalam perspektif Efesus pasal 4:17-32. Kedua, menjelaskan implementasi manusia baru dalam kehidupan orang percaya.

Penulisan karya ilmiah ini menggunakan hermeneutika metode eksegesis Alkitab dan penelitian literatur, dan teknik pengumpulan data yang digunakan oleh penulis ialah mengadakan penelitian atau observasi terhadap Alkitab, dan sebagai sumber pendukung yaitu buku-buku, majalah, naskah, program bible study, dan eksplorasi internet yang ada hubungannya dengan konsep manusia baru.

Adapun kesimpulan karya ilmiah "Konsep Manusia Baru Berdasarkan Perspektif Paulus Dalam Efesus 4:17-32 Dan Implementasinya Dalam Kehidupan Orang Percaya" adalah: Pertama, manusia lama adalah manusia yang berjalan berdasarkan pengertiannya sendiri, tidak mengenal Allah, memiliki pikiran yang siasia, pengertiannya digelapkan, jauh dari hidup persekutuan dengan Allah, memiliki hati yang degil, hati tumpul, sehingga menyerahkan dirinya kepada hawa nafsu dan mengerjakan dengan serakah segala macam kecemaran. Kedua, manusia baru adalah manusia yang telah diciptakan menurut kehendak Allah di dalam kebenaran dan kekudusan, di mana orang-orang yang percaya kepada Kristus memiliki kedudukan baru yaitu dari kebinasaan dipindahkan kepada hidup yang kekal dan manusia yang terus diperbaharui serta dipersatukan dengan Kristus. Ketiga, sebagai manusia baru di dalam Kristus, orang percaya tidak lagi menjadi senjata-senjata kelaliman tetapi sebaliknya menjadi senjata-senjata kebenaran dan hidup memuliakan Allah.
\end{abstract}

Kata Kunci: Manusia Baru, Efesus 4:17-32

${ }^{1}$ Darius, alumni S1 STT Jaffray 2012 


\section{PENDAHULUAN}

\section{Latar Belakang}

Salah satu konsep dasar di dalam iman Kristen adalah manusia baru di dalam Kristus. Manusia baru bukan berarti manusia diciptakan dua kali dalam bentuk fisik, melainkan lebih merujuk kepada perubahan karakter sebagai ciptaan baru di dalam Kristus di mana dia tidak lagi hidup di dalam dosa atau diperhamba oleh dosa melainkan telah dimerdekakan dari dosa dan hidup kepada Allah serta memuliakan Allah di dalam seluruh aspek hidupnya.

Disebut sebagai Kristen sejati adalah orang-orang yang telah meninggalkan dosanya, yaitu menanggalkan manusia lamanya serta kelakukannya dan telah mengenakan manusia baru yang terus menerus diperbaharui (Kolose 3:9-10) di dalam Kristus. Chris Marantika berkata bahwa:

Manusia baru adalah (1) seseorang yang menerima bagian dalam kematian Tuhan Yesus dan dosa-dosanya dihapuskan (Roma 5:8-9; 6:5), (2) seseorang yang menerima bagian dalam kebangkitan Tuhan Yesus (Roma 6:5), (3) seseorang yang manusia lamanya disalibkan dan tidak menjadi hamba dosa lagi, (4) seseorang yang memandang dirinya telah mati bagi dosa dan hidup bagi Allah di dalam Kristus Yesus (Roma 6:11), dan (5) seseorang yang tidak memberi dirinya menjadi senjata dosa/kelaliman, tetapi menyerahkan anggota-anggota tubunya kepada Allah untuk menjadi senjata-senjata kebenaran (Roma 6:13). ${ }^{2}$

Richard L. Pratt menambahkan bahwa orang-orang yang percaya dalam Kristus diperbaharui secara terus menerus menurut sifat mereka yang semula sebagai manusia yang diciptakan menurut gambar dan rupa Allah. Mereka diberikan kebenaran, kesucian, dan pengetahuan yang benar, di mana semua itu telah hilang pada waktu kejatuhan. Pembaharuan melalui kelahiran baru tidak hanya meliputi sebagian dari manusia, melainkan meliputi seluruh karakternya, bahkan proses berpikirnya. Manusia tidak diselamatkan untuk sekedar berada dalam keadaan yang manis dan menyenangkan, namun, manusia diperbaharui sebagai ciptaan baru dan dikembalikan kepada asal mula keberadaan manusia sebagai gambar Allah melalui kelahiran baru. ${ }^{3}$

\footnotetext{
${ }^{2}$ Chris Marantika, Kepercayaan dan Kehidupan Kristen (Yogyakarta: Sekolah Tinggi Teologia Injil Indonesia,1996), 139.

${ }^{3}$ Richard L. Pratt, Menaklukkan Segala Pikiran Kepada Kristus (Malang: Seminar Alkitab Asia Tenggara,2003), 57-58.
} 
Berdasarkan pernyataan tersebut di atas maka orang yang di dalam Kristus adalah manusia baru yang terus mengalami pembaharuan di dalam seluruh aspek hidupnya dan manusia lamanya disalibkan serta tidak menjadi hamba dosa lagi. Dia memandang dirinya telah mati bagi dosa dan hidup bagi Allah di dalam Kristus Yesus (Roma 6:1l) dan tidak memberi dirinya menjadi senjata dosa atau kelaliman, melainkan menyerahkan anggota-anggota tubunya kepada Allah untuk menjadi senjata-senjata kebenaran (Roma 6:13). Hal tersebut merupakan suatu gambaran praktika kehidupan Kristen yang benar-benar hidup bagi Allah dan hidup dalam persekutuan dengan Allah. Pernyataan tersebut sejalan dengan pernyataan Paulus di dalam Efesus 4:21-24 "karena kamu telah mendengar tentang Dia dan menerima pengajaran di dalam Dia menurut kebenaran yang nyata dalam Yesus, yaitu bahwa kamu, berhubung dengan kehidupan kamu yang dahulu, harus menanggalkan manusia lama, yang menemui kebinasaanya oleh nafsunya yang menyesatkan, supaya kamu dibaharui di dalam roh dan pikiranmu, dan mengenakan manusia baru, yang telah diciptakan menurut kehendak Allah di dalam kebenaran dan kekudusan yang sesungguhnya." ${ }^{4}$

Pada kenyataannya banyak kalangan Kristen dewasa ini memiliki konsep bahwa manusia baru di dalam Kristus atau seorang yang sudah lahir baru adalah orang yang sudah menjadi Kristen atau menganut agama Kristen serta sudah dibaptis secara ritual gereja. Sehubungan dengan hal tersebut muncul pemahaman bahwa orang itu sudah benarbenar manusia baru (ciptaan baru) di dalam Tuhan. Hal tersebut merupakan suatu konsep atau pemahaman yang berbeda yang perlu diluruskan dalam memahami arti hidup kekristenan yang sebenarnya. Pemahaman yang demikian tidak dapat dipertahankan sebab dapat merusak konsep dasar hidup kekristenan bagi generasi-generasi baru di dalam gereja. Bukankah Yesus pernah berkata Nikodemus di dalam Yohanes 3:1-21 Yesus berkata, "Aku berkata kepadamu, sesungguhnya jika seorang tidak dilahirkan kembali, ia tidak dapat melihat kerajaan Allah." Pernyataan ini mengandung arti bahwa seseorang harus benarbenar percaya kepada Kristus sebagai Tuhan, menyerahkan hidupnya kepada Tuhan (Roma 6:13), memiliki pengenalan akan Allah, serta meninggalkan kehidupan yang lama yang penuh dengan dosa (Efesus 4:22), lalu mengenakan manusia baru yang telah diciptakan oleh Allah di dalam Yesus Kristus.

Cara hidup yang demikian belum sepenuhnya dihidupi oleh gereja sehingga dapat mengakibatkan gereja tidak memberikan kesaksian yang baik bagi orang-orang yang belum percaya, khususnya di kalangan Kristen sendiri. Selain itu, gereja gagal dalam menyatakan misi Allah bagi

${ }^{4}$ Efesus 4:21-24 (TB) 
dunia sebab sadar atau tidak, kehidupan gereja nampak dalam praktik kehidupan yang dapat dilihat dan dibaca oleh dunia. Pada masa kini tidak sedikit warga gereja hidup di dalam kesenangan dosa dan tidak sungguh-sungguh hidup sebagai ciptaan baru di dalam Kristus. Tidak dapat disangsikan bahwa masih banyak orang Kristen yang belum sungguh-sungguh meninggalkan kehidupan yang lama yaitu kehidupan yang penuh dengan dosa dan tidak mengenakan kehidupan yang baru di dalam Kristus.

Bertitik tolak dari latar belakang masalah yang ada, maka dalam penulisan karya ilmiah ini akan dibahas konsep pengajaran Paulus tentang manusia baru, di mana penulis tidak akan membahas konsep manusia baru di dalam seluruh Perjanjian Baru, tetapi penulis akan melihat konsep manusia baru menurut Paulus di dalam surat Efesus pasal 4:17-32 yang dibahas dalam karya ilmiah ini. Konsep tersebut diangkat dalam judul karya ilmiah ini adalah "Konsep Manusia Baru Berdasarkan Perspektif Paulus Dalam Efesus 4:17-32 Dan Implementasinya Dalam Kehidupan Orang Percaya."

\section{Pokok Masalah}

Beberapa pokok permasalahan yang penulis akan bahas dalam karya ilmiah ini yaitu: Pertama, apakah arti manusia baru berdasarkan perspektif Paulus di dalam surat Efesus pasal 4:17-32? Kedua, bagaimana mengimplementasikan arti manusia baru dalam kehidupan orang percaya?

\section{Tujuan Penulisan}

Tujuan dalam penulisan karya ilmiah ini adalah: Pertama, menjelaskan konsep biblika mengenai manusia baru dalam perspektif Efesus pasal 4:17-32. Kedua, menjelaskan implementasi manusia baru dalam kehidupan orang percaya.

\section{Manfaat Penulisan}

Adapun manfaat penulisan karya ilmiah ini adalah: Pertama, untuk memberikan sumbangsih pengetahuan dalam hal konsep manusia baru dalam perspektif Paulus kepada seluruh orang Kristen supaya mereka memiliki konsep yang benar tentang manusia baru. Bukan hanya sebatas pengetahuan tetapi juga untuk mengubah karakter dan hidup di dalam mengenakan manusia baru di dalam Kristus. Kedua, untuk menambah wawasan dan pengetahuan penulis di dalam membangun teologi yang benar tentang manusia baru, tetapi juga untuk mengubah karakter penulis, dan kepada hamba-hamba Tuhan, serta kepada Almamater tercinta STT Jaffray Makassar. 


\section{Metode Penulisan}

Dalam penulisan karya ilmiah ini, penulis menggunakan metode eksegesis Alkitab dan penelitian literatur, di mana penulis mengadakan penelitian buku-buku, eksplorasi internet yang mengkaji konsep manusia baru dalam perspektif Paulus, khususnya dalam surat Efesus pasal 4:17-32.

\section{Batasan Penulisan}

Pada penulisan karya ilmiah ini, penulis membatasi tulisan ini pada pengajaran Paulus tentang manusia baru khususnya di dalam surat Efesus pasal 4:17-32. Adapun penulis membahas dari kitab lain, namun itu hanya digunakan sebagai bahan perbandingan saja yang ada hubungannya dengan manusia baru berdasarkan perspektif Paulus dalam surat Efesus pasal 4:17-32.

\section{ANALISIS MANUSIA BARU DALAM SURAT EFESUS 4:17-32}

\section{Analisa Konteks}

Sebelum melakukan penafsiran terhadap Efesus pasal 4:17-5:21 tentang manusia baru, terlebih dahulu akan dilakukan analisa konteks pada bagian sebelum dan sesudah teks untuk mengetahui informasi yang berhubungan dengan teks. Dalam pasal-pasal sebelumnya memberikan suatu gambaran tentang keadaan lama yaitu keadaan di luar Allah dengan keadaan baru di dalam Kristus. ${ }^{5}$ Ada dua penekenan penting yang digambarkan dalam Efesus 2:1-22 yaitu:

\section{Keadaan Manusia Lama}

Manusia lama adalah manusia dalam keadaan mati tanpa pengharapan (Efesus 2:1-10). Berikut ada beberapa ulasan tentang kehidupan orang yang di luar Allah yaitu;

Pertama, keadaan mati. Dikatakan dalam Efesus 2:1, "Kamu dahulu sudah mati karena pelanggaran-pelanggaran dan dosamu." Sidlow Baxter mengatakan bahwa hakekat maut bukannya perhentian tapi perpisahan. Matinya tubuh berarti tubuh berpisah dari roh; sedang matinya roh berarti roh berpisah dari Allah, hilangnya hidup yang tertinggi yang manusia punya dahulu sebelum dosa memisahkannya dari Allah sumber hidupnya. ${ }^{6}$ Menurut R. E. Harlow bahwa kehidupan yang lama sungguh-

\footnotetext{
${ }^{5}$ J. Sidlow Baxter, Menggali Isi Alkitab:Roma Sampai dengan Wahyu (Jakarta: Yayasan Komunikasi Bina Kasih, 2011), 107.

${ }^{6}$ Ibid., 107.
} 
sungguh mati, mati rohani. Ketika seseorang mati, maka rohnya akan berpisah dari tubuhnya, di dalam Yakobus 2:26 berkata bahwa tubuh tanpa roh adalah mati. Ini adalah kematian secara alami. Tetapi ketika seseorang berdosa, maka ia akan berpisah dari Allah. Hal ini disebut sebagai kematian rohani. ${ }^{7}$ Analisa Paulus terhadap dua bentuk sisi kematian bagi manusia merupakan dua fakta yang sungguh-sungguh terjadi dalam kehidupan manusia. Kematian secara alami yaitu di mana tubuh berpisah dengan roh akan dialami oleh setiap manusia. Paulus hanya menggunakan gambaran tersebut untuk menjelaskan makna yang lebih dalam tentang kematian. Ketika seseorang di luar Allah itu berarti dirinya berpisah dari Allah, maka ia akan mengalami kematian kekal, tanpa pengharapan, dan akan mengalami penghakiman.

Kedua, manusia taat kepada iblis (Ef 2:2) "Kamu mengikuti jalan dunia ini karena kamu menaati penguasa kerajaan angkasa, yaitu roh yang sekarang sedang bekerja di antara orang-orang durhaka." Yang dimaksud dengan itu adalah roh-roh jahat atau iblis yang menguasai kehidupan manusia dan manusia di bawah kendali kuasa kegelapan, sehingga manusia tidak dapat melihat terang Kristus. Maksudnya adalah bahwa semua manusia di dunia ini hidup di dalam dosa dan semua orang mengikuti cara hidupnya. Mereka taat kepada setan yang adalah roh kejahatan dan yang menguasai manusia di dunia ini. ${ }^{8}$ Itulah sebabnya konteks surat Paulus ini berbicara tentang kondisi manusia lama yaitu manusia dunia yang tidak percaya yang hidupnya dikuasai oleh setan. Namun, bukan hanya hidupnya di bawah kontrol atau kuasa iblis tetapi hidup tanpa pengarapan.

Ketiga, manusia di bawah kuasa hawa nafsu daging (Efesus 2:3)“ Kami hidup di bawah hawa nafsu daging dan pikiran kami yang jahat." Artinya bahwa manusia di bawah nafsu, kehendak dan pkiran-pikiran yang terikat pada dunia, sehingga membuat manusia hidup melakukan apa yang jahat.

Keempat, akibat semuanya itu, manusia mengalami murka Allah atau penghukuman yang berasal dari Allah (Efesus 2:3), "Pada dasarnya kami adalah orang-orang yang harus dimurkai, sama seperti mereka yang lain." Semua hal tersebut di atas harus mendapat hukuman karena berhubung dengan diri Allah yang kudus, di mana Allah harus menghapuskan dosa.

13. 13.
${ }^{7}$ R. E. Harlow, Ephessians in the Beloved (Canada: Everyday Publication INC, 1984),

${ }^{8}$ R. E. Harlow, Ephessians in the Beloved (Canada: Everyday Publication INC, 1984), 


\section{Keadaan Manusia Baru}

Manusia baru adalah manusia yang dihidupkan oleh Allah (Efesus 2:5-10).Semua keadaan manusia tersebut di atas patut dimurkai oleh Allah. Namun, karena Allah sangat mengasihi manusia, maka Ia mengutus Yesus Kristus adalah anak-Nya yang tunggal menjadi pendamai antara Allah dan manusia sehingga terjadi pertalian yang baru. Ada beberapa hal penting berhubungan dengan manusia baru yaitu;

Pertama, manusia dihidupkan kembali di dalam Kristus (Efesus 2:5). Allah "telah menghidupkan kita bersama-sama dengan Kristus."Artinya bahwa manusia yang dahulu mati karena perbuatanperbuatan dosa dan pelanggaran kepada Allah harus mati, tetapi Allah menghidupkan kembali di dalam Yesus Kristus.Ini merupakan anugerah Allah bagi manusia sehingga manusia boleh menikmati anugerah Allah. His mercy is rich and His love is great. ${ }^{9}$ Pernyataan ini merupakan suatu tindakan nyata yang diberikan Allah kepada setiap orang percaya sehingga dapat mengalami kehidupan baru di dalam Kristus yang mengerjakan penebusan dan menciptakan manusia baru.

Kedua, manusia dibangkitkan (Efesus 2:6) "Dan di dalam Yesus Kristus Ia telah membangkitkan kita." Yesus bukan hanya menghidupkan manusia tetapi juga membangkitkan manusia. Kebangkitan Kristus memberikan hidup baru bagi setiap orang percaya dan melepaskan orang percaya dari perhambaan. ${ }^{10}$ Maksudnya adalah bahwa Allah membangkitkan Kristus dari kematian dan sebagai hasilnya manusia mendapatkan berkat yang besar. Kebangkitan Kristus memberikan pengharapan bahwa setiap orang percaya akan duduk bersama-sama Kristus di sorga. ${ }^{11}$

Ketiga, manusia mendapat mahkota yaitu mendapat tempat yang mulia bersama Bapa di sorga (Efesus 2:6) "Dan memberikan tempat bersama-sama dengan Dia di sorga." Artinya bahwa manusia akan menikmati sukacita sorga bersama dengan Kristus.

Keempat, manusia diberi kasih karunia oleh Allah (Efesus 2:8,9). Dahulu kita "orang-orang yang harus dimurkai", tetapi sekarang tidak demikian lagi karena pada masa yang akan datang, Ia (Allah) menunjukkan kekayaan-Nya yang melimpah-limpah dari kasih karuniaNya menurut kehendak-Nya kepada kita dalam Kristus Yesus. Itulah sebabnya tidak mengherankan kalau Paulus dua kali berseru dalam Efesus bahwa "Karena kasih karunia kamu diselamatkan", kemudian ia

\footnotetext{
${ }^{9}$ Ibid., 14.

${ }^{10} \mathrm{~J}$. Sidlow Baxter, Menggali Isi Alkitab:Roma Sampai dengan Wahyu (Jakarta: Yayasan Komunikasi Bina Kasih, 2011), 109.

${ }^{11}$ R. E. Harlow, Ephessians in the Beloved (Canada: Everyday Publication INC, 1984), 14.
} 
berkata, "itu bukan karena hasil pekerjaanmu: jangan ada orang yang memegahkan diri (Efesus 2:8,9)." Oleh karena itu, Paulus menjelaskan dalam Efesus 2:11-12 bahwa manusia dahulu hidup di dalam daging, tanpa Kristus yaitu tidak termasuk kewargaan Israel dan tidak mendapat bagian dalam ketentuan-ketentuan yang dijanjikan oleh Allah di dalam Yesus Kristus, tanpa pengharapan, dan tanpa Allah di dalam dunia.

Dalam Efesus pasal 4, Paulus berkata, "Sebab itu aku menasihatkan kamu, aku orang yang dipenjarakan karena Tuhan, supaya hidupmu sebagai orang-orang yang telah dipanggil berpadanan dengan panggilan itu." Hal ini menunjukkan bahwa Paulus ingin supaya jemaat harus bersungguh-sungguh hidup memuliakan Allah. Paulus ingin supaya jemaat itu atau orang-orang kudus dan orang-orang percaya (Efesus l:1) memiliki ketaatan penuh kepada Allah, karena Allah telah menganugerahkan segala kekayaan yaitu kasih karunia-Nya atas segala berkat rohani di dalam sorga (Efesus 1:3), yang dalam Kristus dipilih menjadi anak-Nya (Efesus 1:4-5), yang dibangkitkan bersama-sama dengan Kristus dan ditempatkan dengan Dia di dalam sorga, sekalipun mereka ada di dalam bumi (2:6), yang oleh darah Kristus diperdamaikan dengan Allah (Efesus 2:13-14) sehingga mereka juga beroleh jalan masuk kepada Bapa dan menjadi sewarga dengan orang-orang kudus dan anggota-anggota keluarga Allah (2:18-19), bahkan turut menjadi ahli waris serta memperoleh janji-janji yang diberikan dalam Kristus Yesus (3:6). Oleh sebab itu, Paulus menginginkan supaya jemaat di Efesus benar-benar hidup taat kepada Allah dan memuliakan Allah sebagai ciptaan baru di dalam Kristus serta sebagai orang-orang yang telah dipanggil dan dipilih oleh Allah.

\section{Manusia Lama (4:17-19)}

Pengajaran Paulus dalam surat Efesus 4:17-32 memperlihatkan secara jelas perbedaan antara kehidupan orang yang tidak mengenal Allah (manusia lama) dengan kehidupan orang yang mengenal Allah artinya orang yang sudah menerima Kristus secara utuh dalam hidupnya (manusia baru). Gambaran ini bertujuan untuk memperlihatkan bahwa orang yang hidup dalam kehidupan yang lama akan menempuh kebinasaan oleh karena nafsunya yang menyesatkan (Efesus 4:22). Bahkan Paulus sendiri secara terang-terangan mengklaim dalam bukunya bahwa "di luar Kristus tidak ada keselamatan."12

Ada beberapa keadaan orang-orang yang hidup dalam manusia lama yang dijelaskan secara terperinci pada bagian ini yaitu: 2008), 89 .

${ }^{12}$ Herman Ridderbos, Paulus: Pemikiran Utama Teologinya (Surabaya: Momentum, 


\section{Tidak Mengenal Allah (4:17)}

Pada bagian ini Paulus menggunakan kata penghubung "sebab itu" dalam bahasa Yunani oûv oun ${ }^{13}$ yang berarti "kemudian, karena itu, oleh karena" merupakan penghubung dan bukan merupakan suatu kesimpulan tetapi untuk menekankan kembali (Ef 4:1) ${ }^{14}$ yaitu penegasan nasihat Paulus kepada jemaat Efesus supaya hidup sesuai dengan panggilan itu. Paulus berkata, "kutegaskan"15 bahwa "jangan hidup lagi sama seperti bangsa-bangsa " $\epsilon \nu \eta$ (etne) $^{16}$ yang tidak mengenal Allah". Terjemahan KJV yaitu "walk" $\epsilon \in \rho \iota \pi \alpha \tau \epsilon \nu$ (peripatein) ${ }^{17}$ yang berarti berjalan, membuat jalan seseorang, membuat jalan sendiri untuk hidup, mengatur kehidupan berdasarkan diri sediri, melakukan sesuatu berdasarkan diri sendiri. ${ }^{18}$ Perhatikan present aktif indikatif yang berarti tindakan yang dilakukan pada saat ini (pada saat penulis menulis tulisannya). Maksudnya adalah pada saat Paulus menulis suratnya, ia menasihatkan kepada jemaat supaya jangan mengikuti jalan sama seperti bangsabangsa pada saat ini yaitu bangsa-bangsa yang berjalan dengan membuat jalan mereka sendiri untuk hidup, bangsa-bangsa yang mengatur kehidupan berdasarkan diri sendiri, atau melakukan segala sesuatu beradasarkan diri-sendiri dimana mereka hidup di dalam hawa nafsu, menuruti kedagingan (Efesus 2:1-4) dan pikiran mereka yang sia-sia (Ef 4:17). Paulus menegaskan bahwa jangan mengikuti jalan mereka dan jangan meniru kehidupan orang-orang yang belum selamat, sebab apa yang mereka lakukan itu adalah sia-sia belaka dan tidak ada kehidupan di dalamnya sebab mereka mati karena pelanggaran-pelanggaran dan dosa-dosa mereka (Efesus 2:1). Sedangkan orang Kristen telah

13 "oûv"(oun) merupakan kata penghubung yang berasal dari kataou=nyaitu sebuah partikel, yang berarti varies with the context, and sometimes oun may be left untranslated and inferential therefore, consequently, accordingly. (BMG Morphology, Word Analysis, s.v. "oûv" In Bible Works Version 7). 2009), 145

${ }^{14}$ J. L. Ch. Abineno, Tafsiran Alkitab Surat Efesus (Jakarta: BPK Gunung Mulia,

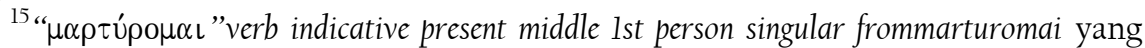
berarti menyatakan, menerangkan, dan menjelaskan. Sehubungan itu, (BMG Morphology,

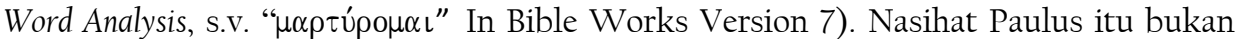
saja mengandung berita karya penyelamatan Allah (Bdg. I Kor 15:15), tetapi juga kesaksian tentang berita itu, supaya anggota-anggota jemaat bersungguh-sungguh mendengarkan kesaksian penjelasan yang diberikan oleh Paulus.

${ }^{16}$ "' $\epsilon \nu \eta$ ” noun nominative neuter plural yang berasal dari kata etnos yang berarti race, nation (dalam bentuk jamak yaitu ras-ras atau bangsa-bangsa) (Strong's, Word Analysis, s.v. "Gentiles" In Bible Works Version 7).

${ }^{17}$ “ $\pi \epsilon \rho \iota \pi \alpha \tau \epsilon \iota$ " verb indicative present active 3rd person singular yang berasal dari kata

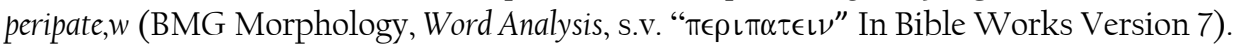

${ }^{18}$ Strong's, Word Analysis, s.v. "Walk" In Bible Works Version 7. 
dibangkitkan dari antara orang mati dan diberi kehidupan yang kekal di dalam Kristus. ${ }^{19}$

\section{Pikiran yang Sia-Sia (4:17b)}

Maksud Paulus dengan pikiran yang sia-sia (mataioteti) ${ }^{20}$ yaitu tidak memiliki kebenaran dan ketepatan, penuh dengan tipu muslihat, kebejatan, dan kelemahan ${ }^{21}$ atau kesombongan, kehampaan. ${ }^{22}$ Itulah sebabnya Paulus mengatatakan bahwa jangan hidup atau berjalan sama seperti bangsa-bangsa yang membuat jalan mereka sendiri dengan pikirannya yang sia-sia, ${ }^{23}$ yaitu penuh dengan tipu muslihat, penuh dengan kebejatan, dan tidak ada kebenaran di dalam mereka, kesombongan, dan kehampaan di dalam pikiran mereka sebab pikiran atau pengertian (Efesus 4:18) mereka digelapkan oleh penguasa kerajaan angkasa yaitu roh yang bekerja di antara orang durhaka sehingga tidak dapat mengenal Allah (Efesus 2:2).

\section{Pengertian yang Gelap (4:18a)}

Selanjutnya paulus mengatakan bahwa mereka memiliki "pengertian yang gelap." Yang dimaksudkan oleh Paulus di sini adalah

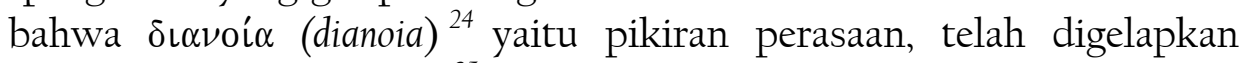

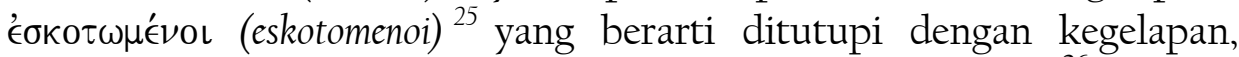
digelapkan, pemahaman atau pikiran mereka menjadi gelap. ${ }^{26}$ Pikiran orang yang belum selamat itu menjadi sia-sia karena pikirannya digelapkan dan mereka mengira bahwa mereka berpengetahuan karena percaya kepada filsafat-filsafat modern padahal sebenarnya mereka ada dalam kegelapan. Roma 1:22 mengatakan bahwa "mereka berbuat seolaholah mereka penuh hikmat, tetapi mereka telah menjadi bodoh", dan iblis

\footnotetext{
${ }^{19}$ Warren W. Wiersbe, Kaya di Dalam Kristus (Bandung: Yayasan Kalam Hidup, 2001), 102.

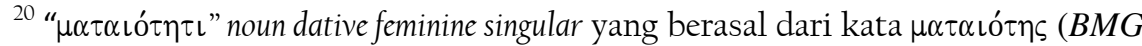

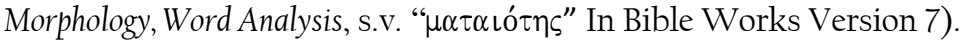

${ }^{21}$ Strong's, Word Analysis, s.v. "Vanity” In Bible Works Version 7.

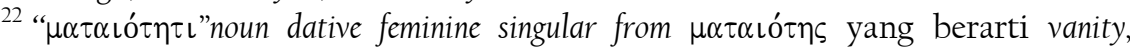
emptinesss. Kata ini berkasus datif (objek tidak langsung) karena diawali dengan kata $\epsilon \nu$ (en) yang berarti in, by, with (di/dalam, oleh, dengan) (BMG Morphology, Word Analysis, s.v.

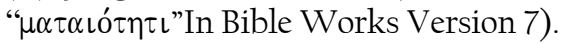

${ }^{23}$ Warren W. Wiersbe, Kaya di Dalam Kristus (Bandung: Yayasan Kalam Hidup, 2001), 103.

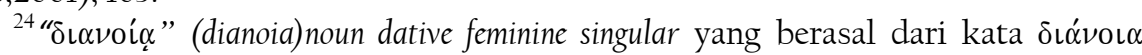

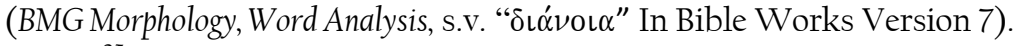

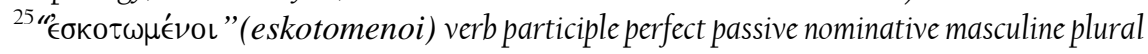

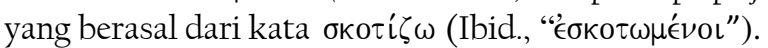

${ }^{26}$ Strong's, Word Analysis, s.v. "Darkened" In Bible Works Version 7.
} 
membutakan pikiran mereka (II Kor 4:3-6) karena iblis tidak ingin mereka melihat kebenaran dan terang di dalam Yesus Kristus, sehingga bukan hanya mata hati mereka yang dibutakan tetapi juga pikiran sehingga mereka tidak dapat memikirkan hal-hal rohani. ${ }^{27}$

\section{Jauh Dari Hidup Persekutuan dengan Allah (4:18b)}

Selain dari tidak mengenal Allah karena pikiran mereka yang siasia dan pengertiannya digelapkan, Paulus juga mengatakan bahwa mereka "jauh dari hidup persekutuan dengan Allah." Kata "jauh" dalam

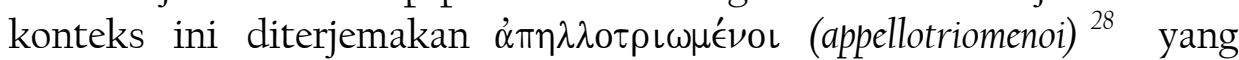
berarti mengasingkan, menjauhkan, akan dikucilkan dari persekutuan seseorang dan keintiman, "akan terasing dengan," atau menjadi asing. ${ }^{29}$ Penggunaan participle perfect passive pada kata ini mengacu kepada tindakan yang telah dilakukan sehingga sebagai akibatnya hal itu terus berlanjut (konsekuensi) yaitu jauh (terpisah atau terasing). Oleh sebab itu, sebagai akibat dari pikiran mereka yang sia-sia dan pengertiannya digelapkan, maka hidup mereka "terasing" ${ }^{30}$ atau terpisah dari persekutuan dengan Allah.

\section{Kebodohan (4:18c)}

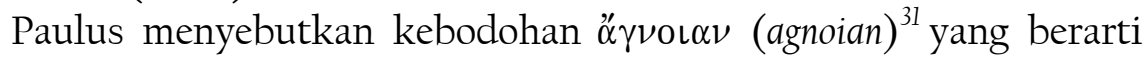
ketidaktahuan, kurangnya pengetahuan, ketidaktahuan dari hal-hal ilahi, dan kebutaan moral. ${ }^{32}$ Paulus menegaskan bahwa jangan berjalan seperti bangsa-bangsa dengan pikirannya yang sia-sia, pengertiannya yang telah digelapkan, terasing atau terpisah dari persekutuan dengan Allah melalui ketidaktahuan dari hal-hal ilahi, kurangnya pengetahuan, atau kebutaan moral yang ada di dalam mereka. Menurut Matthew Henry bahwa dalam hidup terasing dari Allah, mereka memiliki kebencian dan keengganan untuk hidup yang dalam kekudusan,

\footnotetext{
${ }^{27}$ Warren W. Wiersbe, Kaya di Dalam Kristus (Bandung: Yayasan Kalam Hidup, 2001), 103.

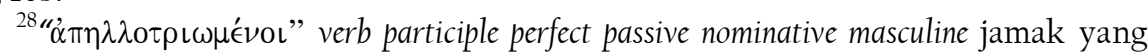

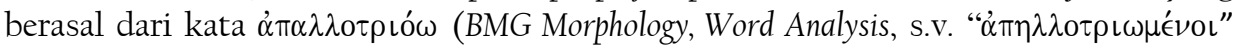
In Bible Works Version 7).

${ }^{29}$ Strong's, Word Analysis, s.v. "Alienated” In Bible Works Version 7.

30 "Terasing" mengandung arti perpisahan atau kesendirian (kesunyian). Terasing adalah sesuatu, yang karena diceraikan dari maksud/tujuannya dan dicabut dari tempat, di mana ia hidup, telah kehilangan maknanya yang sebenarnya dan sekarang merana dan mati, disia-siakan dan binasa, demikianlah "terasing dari hidup persekutun dengan Allah" dekat sekali artinya dengan mati." (J.L. Ch. Abineno, 149).

31 " $\alpha \gamma \nu 0\llcorner\alpha \nu$ " noun accusative (objek langsung) feminine singular yang berasal dari

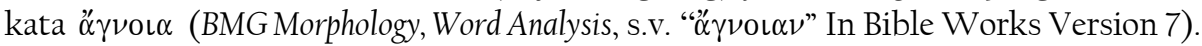

${ }^{32}$ Strong's, Word Analysis, s.v. "Ignorance" In Bible Works Version 7.
} 
kemurnian, kebenaran, dan kebaikan. Karena kebodohan mereka menyebabkan keterasingan mereka dari Allah dan merusak agama dan kesalehan. Yang menyebabkan mereka menjadi bodoh adalah karena kedegilan atau kekerasan hati mereka. Bukan Tuhan yang membuat dirinya untuk tidak ingin diketahui oleh mereka dengan karya-Nya, tetapi karena mereka tidak mau mengakui dan menerima cahaya ilahi. Ketidaktahuan mereka berangkat dari sikap yang keras kepala dan kekerasan hati mereka dengan menolak cahaya ilahi serta pengetahuan. ${ }^{33}$

\section{Kedegilan Hati (4:18d)}

Yang menyebabkan mereka memiliki pengertian yang gelap sehingga jauh dari hidup persekutuan dengan Allah adalah melalui kebodohan dan juga kedegilan $\pi \omega ́ \rho \omega \sigma \iota \nu$ (porosin) ${ }^{34}$ yang berarti kedegilan, ${ }^{35}$ kebutaan, kekerasan, persepsi tumpul, pikiran seseorang yang telah tumpul, serta keras kepala atau sifat keras kepala. ${ }^{36}$ Porosis berasal dari kata poros yang berarti batu yang lebih keras dari pada batu pualam. ${ }^{37}$ Maksud Paulus di sini bahwa yang mengakibatkan orangorang kafir jauh dari hidup persekutuan dengan Allah adalah karena pikiran mereka telah tumpul, hati mereka buta dan keras.

\section{Perasaan Tumpul (4:19)}

Keadaan lain yang terdapat dalam kehidupan bangsa-bangsa yang tidak mengenal Allah adalah "perasaan yang tumpul" KJV: "pass feeling" $\dot{\alpha} \pi \eta \lambda \gamma \eta \kappa o ́ \tau \epsilon \varsigma$ (apelgekotes) ${ }^{38}$ yang berarti mati rasa, menjadi putus asa, tidak memiliki perasaan, bersikap apatis, hilang perasaan atau tidak ada kesadaran dalam hati mereka. ${ }^{39}$ Di sini Paulus selalu menggunakan participle perfek menunjukkan tindakan pada masa lampau yaitu

\footnotetext{
${ }^{33}$ Matthew Henry, Matthew Henry's Commentary "Efesus 4:17-32" In PC Study Bible Version 5.

34“ " $\omega \omega \rho \omega \sigma \iota \nu$ ” noun accusative feminine singular yang berasal dari kata $\pi \omega \dot{\rho} \omega \sigma \iota \varsigma$ dan diawali dengan $\delta \iota \dot{\alpha}$ (dia) kasus genetif yang berarti through (melalui) yang juga berarti bersumber dari diri mereka sendiri.(BMG Morphology, Word Analysis, s.v. " $\pi \omega \rho \omega \sigma \iota \nu$ " In Bible Works Version 7).

35 Hasan Sutanto, Perjanjian Baru Interlinear Yunani-Indonesia dan Konkordansi Perjanjian Baru Jilid 2 (Jakarta: Lembaga Alkitab Indonesia, 2010), 690.

${ }^{36}$ Strong's, Word Analysis, s.v. "blindness" In Bible Works Version 7.

${ }^{37}$ William Barclay, Pemahaman Alkitab Setiap Hari: Galatia-Efesus (Jakarta: BPK Gunung Mulia, 1983), 227.

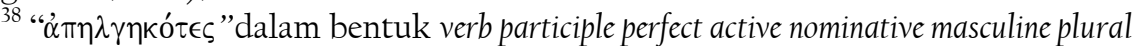

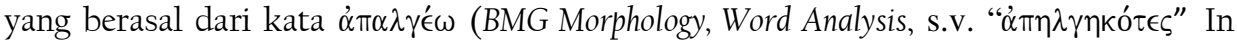
Bible Works Version 7). 2009), 150 .

${ }^{39}$ J. L. Ch. Abineno, Tafsiran Alkitab Surat Efesus (Jakarta: BPK Gunung Mulia,
} 
keputusan yang diambil untuk menuruti keinginan sendiri, berjalan berdasarkan pengertian sendiri yang mengakibatkan hati menjadi mati rasa, putus asa, tidak berperasaan, bersikap apatis, bahkan tidak ada kesadaran dalam hati atas dosa, atas kesia-siaan, sehingga memberi diri kepada hawa nafsu (4:19).”

\section{Manusia Baru (4:20-32)}

Warren W. Wiersbe dalam bukunya mengatakan bahwa orang Kristen mempunyai cara berpikir yang berbeda dengan orang-orang yang belum percaya (selamat) dalam hal pikiran (ayat 17,23), pengertian (ayat 18), kebodohan mereka (ayat 18). Keselamatan dimulai dari pertobatan yang berarti perubahan hati. Apabila seseorang percaya kepada Kristus, seluruh pandangannya berubah, termasuk penilaiannya, tujuannya, bahkan penafsirannya mengenai kehidupan ini. Namun apa yang salah dengan orang-orang yang belum selamat? Bagaimanapun juga pikiran mereka itu sia-sia. Pikirannya tidak mencapai tujuan yang berarti, karena ia tidak mengenal Allah, ia tidak dapat mengerti dengan sungguh dunia di sekelilingnya dan tidak dapat memahami dirinya sendiri. ${ }^{40}$

Sehubungan dengan keadaan orang-orang percaya di dalam Kristus sebagai ciptaan baru (manusia baru), maka berikut ini beberapa gambaran kehidupan praktis sebagai ciptaan baru (manusia baru) di dalam Kristus.

\section{Belajar Mengenal Kristus (4:20)}

Perbedaan yang cukup signifikan antara orang kafir dengan orang percaya, di mana orang kafir tidak mengenal Allah karena pikiran mereka yang sia-sia, pengertian mereka yang gelap, jauh dari hidup persekutuan dengan Allah karena kebodohan dan kedegilan hati mereka yang mengakibatkan hati mereka menjadi tumpul sehingga mereka menyerahkan diri mereka kepada hawa nafsu dan mengerjakan segala kecemaran (4:17-19). Sedangkan orang-orang yang percaya di dalam Kristus mereka hidup di dalam pengenalan akan Allah, serta roh dan pikiran mereka dibaharui (4:20-23). "Kamu" (orang-orang kudus di Efesus yaitu orang-orang percaya dalam kristus 1:2) telah belajar mengenal Kristus." Kristus adalah satu-satunya Firman dan jawaban ilahi, satu-satunya percakapan ilahi, satu-satunya perubahan ilahi, satusatunya pembaharuan, dan pembangkitan serta di dalam Dia ada hidup. Oleh sebab itu, mereka (jemaat Efesus) tidak boleh lagi mengikuti hidup orang-orang kafir. Kata "mengenal" tidak digunakan dalam ayat ini, tetapi menggunakan kata "learned Christ" (belajar Kristus) ' $\mu \alpha \dot{\theta} \theta \epsilon \tau \epsilon$

${ }^{40}$ Warren W. Wiersbe, Be Rich: Are You Losing the Things That Money Can't Buy? (United Stated of Amerika: A Division Of SP Publication INC, 1973), 108. 
(ematete) $^{41}$ aorist aktif indikatif mengacu kepada peristiwa masa lampau, yang sebenarnya mengacu kepada ayat 24 yaitu "berhubung dengan kehidupan kamu yang dahulu, harus menanggalkan manusia lama" yaitu suatu peristiwa yang sekali terjadi yaitu menanggalkan manusia lama lalu datang kepada Kristus sebagai kebenaran yang sesungguhnya, sehingga pengertian aorist aktif indikatif adalah jemaat Efesus telah menanggalkan manusia lama dan telah belajar, memiliki pemahaman, pengetahuan tentang Kristus. Itulah sebabnya Paulus mengatakan bahwa "tetapi kamu bukan demikian" artinya orang percaya berbeda cara hidupnya dengan orang-orang kafir sebab orang percaya telah belajar mengenal Kristus berarti memunyai hubungan dengan Kristus sehingga dari hari ke hari memiliki pengenalan akan Dia ${ }^{42}$ yaitu mendengarkan Dia, menerima pengajaran-Nya yang sesuai dengan kebenaran yang nyata di dalam Yesus (4:20-21). Mengenal Allah juga ditandai dengan persekutuan dengan Allah yaitu persekutuan di dalam Firman Allah. ${ }^{43}$

\section{Menanggalkan Manusia Lama (4:22)}

Sebagai orang percaya yang benar-benar baru di dalam Kristus, ada suatu tindakan yang perlu dilakukan yaitu menanggalkan manusia lama yakni keadaan manusia yang digambarkan oleh Paulus dalam (Pasal 4:1719). Paulus memberikan pengertian dengan menggunakan bentuk aorist medium infinitive dari kata apotestai sebenarnya menunjukkan tindakan satu kali untuk selama-lamanya yaitu menanggalkan atau membuang kehidupan lama yang menemui kebinasaannya oleh nafsunya yang menyesatkan seperti kondisi manusia lama yang dijelaskan dalam (4:1719) yaitu membuang segala kejahatan yang terdapat dalam manusia lama tanpa mengingatnya lagi, lalu mengenakan manusia baru (4:24) di dalam Yesus Kristus.

\section{Mengalami Pembaharuan (4:23)}

Menurut Warren W. Wiersbe bahwa ketika orang percaya menerima Kristus, mereka harus menanggalkan jubah kematian dan tidak mengingatnya lagi dan masuk kepada suatu proses yaitu

\footnotetext{
${ }^{41}$ “ $\epsilon \mu$ ' $\theta \epsilon \tau \epsilon$ "(ematete) verb indicative aorist active 2nd person plural yang berasal dari kata $\mu \alpha \nu \theta \dot{\alpha} \nu \omega$ (mantano) yang berarti belajar, memahami atau meningkatkan pengetahuan seseorang, meningkatkan pengetahuan, mendengar, belajar atau hidup di dalam kebiasaan, terbiasa. (BMG Morphology, Word Analysis, s.v. " $\epsilon \mu \alpha \dot{\alpha} \theta \in \tau \epsilon$ " In Bible Works Version 7). 2001), 104.

${ }^{42}$ Warren W. Wiersbe, Kaya di Dalam Kristus (Bandung: Yayasan Kalam Hidup, ${ }^{43}$ Ibid.
} 
pertobatan, di mana dengan memiliki penyerahan total kepada Allah untuk mengalami pembaharuan di dalam Kristus yaitu persekutuan dengan Firman Allah yang akan membaharui pikiran dan roh. Kata pembaharuan dalam ayat ini digunakan $\alpha \dot{\nu} \alpha \nu \in o v 0 \theta \alpha \iota$ (ananeoustai) verb infinitive present passive from (ananeo) ${ }^{44}$ yang berarti memperbaharui. ${ }^{45}$ Perhatikan kata infinitif presen dari kata $\alpha \nu \alpha \nu \in 0 \hat{\sigma} \theta \alpha \iota$ (ananeoustai) artinya bahwa pembaharuan itu harus berlangsung secara terus menerus dalam kehidupan orang percaya sebagai manusia baru di dalam Kristus. Paulus memberikan pengertian bahwa á $\nu \alpha \nu \in 0 \hat{\sigma} \sigma \theta \alpha \iota$ (ananeoustai) dengan menggunakan presen pasifyang sesungguhnya berarti manusia tidak dapat membaharui dirinya sendiri dan ia hanya dapat memberi dirinya untuk dibaharui, tetapi pembaharuan itu hanya dapat dilakukan oleh Allah. ${ }^{46}$ Namun, manusia dalam hal ini harus memberikan dirinya untuk dibaharui.

Maksud pembaharuan di dalam roh dari pikiran adalah bahwa roh yang menguasai tubuh, jiwa, akal dan hati manusia, ialah Roh Allah, yang dikaruniakan kepada anggota-anggota jemaat, Roh Allah yang menghidupkan mereka dan yang merupakan roh dari hidup mereka yang baru. ${ }^{47}$ Jadi, maksud sebenarnya adalah roh yang ada di dalam diri manusia ketika mengenakan manusia baru di dalam Kristus yang diberikan oleh Allah yang akan membaharui pikiran manusia secara terus-menerus. Kemudian pembaharuan pikiran (4:23) voòs ${ }^{48}$ (noos)yang berarti mind, understanding ${ }^{49}$ (pikiran, pemahaman) merupakan suatu hal yang cukup penting, sebab jika memperhatikan "dibaharui di dalam roh dari pikiranmu" yang berarti menunjuk kepada pikiran sebagai pusat.

\section{Mengenakan Manusia Baru (4:24-32)}

Hal yang paling esensial pada bagian ini seperti yang telah dijelaskan di atas bahwa di dalam Kristus harus menanggalkan manusia lama, lalu mengenakan manusia baru yang telah diciptakan menurut kehendak Allah di dalam kebenaran dan kekudusan yang sesungguhnya.

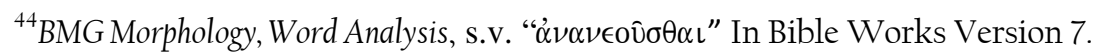

${ }^{45}$ Strong's, Word Analysis, s.v. "be renewed" In Bible Works Version 7.

${ }^{46}$ J. L. Ch. Abineno, Tafsiran Alkitab Surat Efesus (Jakarta: BPK Gunung Mulia, 2009), 156.

${ }^{47}$ J. L. Ch. Abineno, Tafsiran Alkitab Surat Efesus (Jakarta: BPK Gunung Mulia, 2009), 156 .

48 "voòs" noun genitive masculine singular (BMG Morphology, Word Analysis, s.v. "voòs" In Bible Works Version 7).

${ }^{49}$ Strong's, Word Analysis, s.v. "Mind" In Bible Works Version 7.
} 


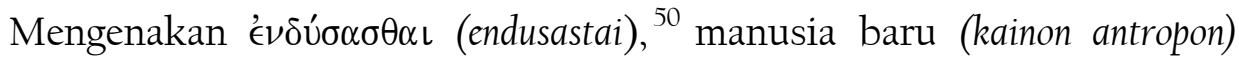
dianalogikan seperti menanggalkan pakaian lama lalu mengenakan pakaian baru. Maksudnya adalah benar-benar masuk ke dalam sesuatu yang baru in the sense of sinking into a garment. Berbeda sekali dengan manusia lama (palaion antropon), di mana manusia lama dikuasai oleh keinginan-keinginan yang jahat, keinginan duniawi, nafsu dunia, bahkan mengerjakan segala kecemaran. Tetapi manusia baru tidak demikian. Ia diciptakan menurut kehendak Allah di dalam kebenaran dan kekudusan yang sesungguhnya. Paulus memberikan pengertian "mengenakan manusia baru," di sini ia menggunakan bentuk aorist middle, di mana ia ingin menekankan bahwa ketika mengenakan manusia baru, itu bukanlah dalam bentuk present tense (sebagai kebiasaan belaka, sekedar dapat dikerjakan setiap hari dan dapat ditukar dengan yang lama apabila bosan) melainkan suatu peristiwa yang sekali dikerjakan maka harus berdampak kekekalan, terus berkelanjutan sampai akhir. Disini Paulus tidak menggunakan bentuk pasif (dalam arti orang itu dipaksa untuk melakukannya) tetapi menggunakan bentuk middle voice yang berarti lebih kearah perlakuan pada diri sendiri yang artinya bahwa sekali memutuskan mengenakan manusia baru, maka harus siap untuk berjalan dalam pertimbangan hidup manusia baru.

Perbedaan yang mencolok dalam manusia baru adalah diciptakan

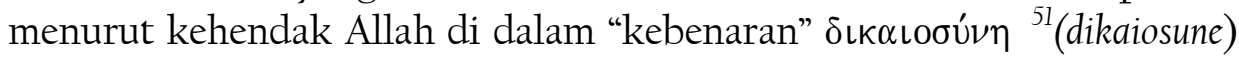
yang berarti righteousness, justice (kebenaran atau keadilan), sedangkan

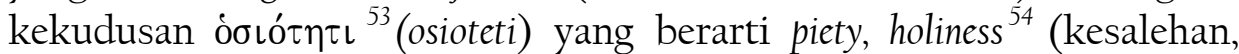
kekudusan). Jadi, Paulus ingin mengatakan bahwa di dalam Kristus harus mengenakan manusia baru yang diciptakan menurut kehendak Allah berdiri di hadapan Allah di dalam "kebenaran, keadilan" dan di dalam "kekudusan atau kesalehan" yang sesungguhnya.

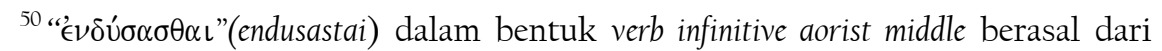
kata é $\nu \delta v^{\prime} \omega$ (enduo) yang berarti memakai, memasukkan, mengenakan, atau dalam arti tenggelam dalam pakaian (Strong's, Word Analysis, s.v. "put on” In Bible Works Version 7).

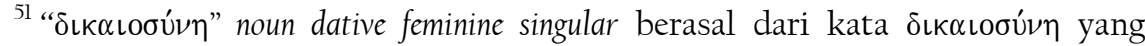
berarti righteousness, justice (kebenaran atau keadilan)dan kata ini diawali dengan $\stackrel{\epsilon}{\nu} \nu$ (en)preposition dative (kata penghubung berkasus datif (objek tak langsung) yang berarti

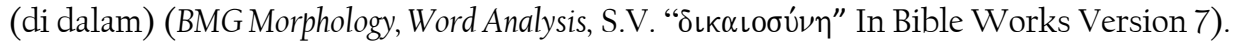

${ }^{52}$ Strong's, Word Analysis, s.v. "Righteousness" In Bible Works Version 7.

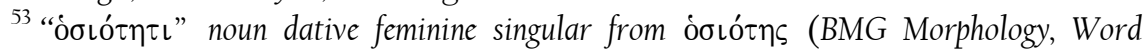

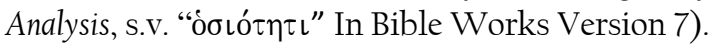

${ }^{54}$ Strong's, Word Analysis, s.v. "holiness" In Bible Works Version 7. 


\section{Perbuatan-Perbuatan yang Harus Dibuang (4:25-31)}

Setelah melihat perbedaan yang cukup signifikan antara kehidupan orang-orang kafir dan kehidupan orang-orang (jemaat) di dalam Kristus, maka selanjutnya Paulus memberikan nasihat-nasihat umum yang bersifat praktis dan kongkret kepada jemaat. Paulus memulai nasihatnya dengan berkata "karena itu" oı (dio) $)^{55}$ yang berarti kata penghubung sebuah kesimpulan berdasarkan atas apa yang telah diuraikan atau sehubungan dengan alasan tersebut. Paulus ingin memberikan suatu nasihat yang merupakan kesimpulan dari manusia

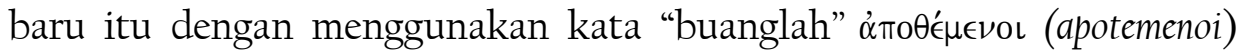
verb participle aorist middle nominative masculine plural yang berasal dari kata $\dot{\alpha} \pi 0 \theta^{\prime} \in \epsilon \in \nu 0{ }^{56}$ yang berarti take off and lay down ${ }^{57}$ (membuka atau meletakkan), put off or lay aside (menanggalkan) ${ }^{58}$ Seperti penjelasan di atas bahwa bentuk participle aorist middle yaitu suatu peristiwa yang sekali dikerjakan maka harus berdampak kekekalan, terus berkelanjutan sampai akhir. Jadi, maksud Paulus di sini adalah jemaat harus meletakkan, menanggalkan, atau membuang perbuatan-perbuatan di dalam jemaat yang seharusnya tidak dapat dilakukan sebagai manusia baru di dalam Kristus dan tidak melakukannya lagi. Jika dibandingkan dengan Efesus 4:13-15, maka sebenarnya nasihat Paulus ini ditujukan kepada dua kelompok orang (jemaat) yaitu kelompok orang-orang yang baru bertobat supaya tetap teguh dalam iman kepada Kristus dengan orang-orang yang dewasa secara rohani supaya mencapai tingkat kedewasaan penuh di dalam Kristus. Oleh sebab itu, sehubungan dengan manusia baru di dalam Kristus, maka jemaat harus membuang semua perbuatan-perbuatan yang merupakan kebiasaan di dalam jemaat.

Berikut ini ada beberapa kebiasaan-kebiasaan di dalam jemaat yang harus dibuang atau ditanggalkan yaitu:

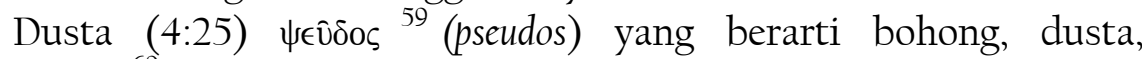
kebohongan. ${ }^{60}$ Warren $\mathrm{W}$. Wiersbe mengatakan:

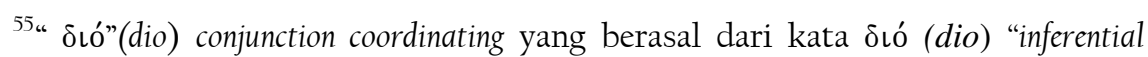
conjunction, therefore, for this reason" (BMG Morphology, Word Analysis, s.v. "סıо,"In Bible Works Version 7).

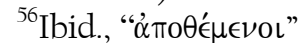

${ }^{57}$ Strong's, Word Analysis, S.V. "Putting away" In Bible Works Version 7.

${ }^{58}$ Ibid., "Put off or Lay aside"

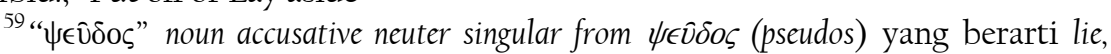

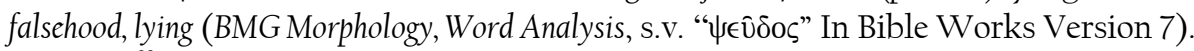

${ }^{60}$ Strong's, Word Analysis, S.V. "Falsehood or lying" In Bible Works Version 7. 
Perhatikan alasan yang diberikan oleh paulus mengapa kita harus berkata benar: kita sama-sama anggota tubuh Kristus. Ia memberikan dorongan kepada kita untuk membangun tubuh Kristus dengan kasih (5:15). Sebagai sesama anggota tubuh Kristus, kita saling mempengaruhi dan kita tidak dapat saling membangun terlepas dari kebenaran. Dosa pertama yang dihakimi dalam jemaat yang mula-mula adalah dusta (Kis. 5:1-11). ${ }^{6}$

Kemarahan (4:26-27). Selain dusta, Paulus juga berkata bahwa jangan ada kemarahan.

Amarah adalah luapan emosi yang disebabkan oleh sesuatu yang tidak menyenangkan. Amarah itu sendiri bukan karena Allah pun dapat menjadi marah (Ul.9:8, 12 Mazmur 2:12). Beberapa kali dalam Perjanjian Lama muncul ungkapan, "Murka Tuhan" (Bil. 25:4; Yer. 4:8; 12:13). Murka Allah adalah bagian dari penghakimanNya atas dosa, sebagaimana dilukiskan dalam kemarahan Tuhan kita Yesus Kristus pada waktu Ia menyucikian bait Allah (Mat. $21: 12-13)^{62}$

Konsep yang lebih jelas diungkapkan oleh Abineno bahwa Tuhan Allah sendiri marah (murka) dan Ia menghendaki, supaya kita juga marah terhadap dosa. Namun, bukan marah ini yang dimaksudkan di sini. Marah di sini yang dimaksudkan adalah amarah yang terus menerus berlangsung, sebab jika hal itu terjadi, maka dapat menimbulkan suatu bahaya yang akibatnya manusia dapat dikuasai oleh iblis sehingga dapat melakukan hal-hal yang tidak bertanggungjawab. ${ }^{63}$ Marah óp $\gamma i \zeta \in \sigma \theta \epsilon$ (orgizeste) ${ }^{64}$ yang berarti to make angry ${ }^{65}$ (menjadi marah). Paulus menggunakan bentuk present, berarti marah adalah sebuah aksi yang dapat menimbulkan kekacauan atau melakukan hal-hal yang tidak dipertanggungjawabkan yang merupakan kebiasaan di dalam jemaat. Paulus sebagai figur yang patut diteladani memberikan suatu perintah imperative bahwa "apabila marah, janganlah kamu berbuat dosa" (4:26). Itulah sebabnya Paulus mengatakan bahwa janganlah matahari

\footnotetext{
${ }^{61}$ Warren W. Wiersbe, Kaya di Dalam Kristus (Bandung: Yayasan Kalam Hidup, 2001), 107.

${ }^{62}$ Ibid., 107. 2009), 158.

${ }^{63}$ J. L. Ch. Abineno, Tafsiran Alkitab Surat Efesus (Jakarta: BPK Gunung Mulia,

64 "O $\rho \gamma i \zeta \epsilon \sigma \theta \epsilon$ " (orgizeste) verb imperative present passive 2nd person plural berasal dari

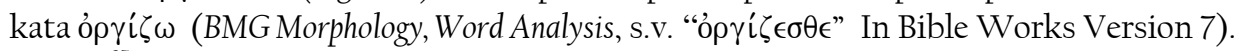

${ }^{65}$ Strong's, Word Analysis, s.v. "Angry" In Bible Works Version 7. 
terbenam, sebelum padam amarahmu. Kemudian "janganlah beri kesempatan kepada iblis (4:27)." Bahaya lain yang diungkapkan oleh Paulus dari kemarahan adalah kesempatan bagi iblis. Selanjutnya Paulus berkata "orang yang mencuri, janganlah ia mencuri lagi (4:28)." Nasihat ini sangat penting karena di dunia kuno pencurian sangat merajalela. Di sini Paulus mengggunakan bentuk present dari kata $\kappa \lambda \in \pi \tau \tau^{\prime} \tau \omega$ (klepteto) $^{66}$ yang berarti pencurian adalah kebiasaan di dalam jemaat yang terus terjadi. Tetapi Paulus memberikan nasihat sebagai ganti mencuri "tetapi

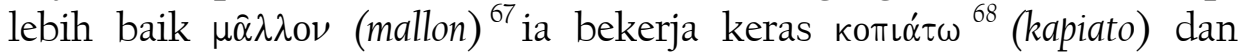
mengerjakan $\rho \gamma \alpha \zeta$ ó $\mu \in \nu$ os ${ }^{69}$ (ergazomenos) pekerjaan yang baik tò $\alpha \gamma \alpha \theta$ ó $^{70}{ }^{70}$ (to agaton) dengan tangannya sendiri supaya ia dapat membagikan sesuatu kepada orang yang berkekurangan." Maksud Paulus di sini adalah bahwa orang yang mencuri janganlah ia mencuri lagi, tetapi lebih baik ia bekerja keras atau berjuang mengerjakan pekerjaan yang baik. Namun, Paulus tidak sampai di situ, ia memberikan nasihat umum bahwa sebagai sesama anggota Tubuh Kristus jemaat harus saling membantu bagi orang-orang yang berkekurangan.

Paulus berkata, "janganlah ada perkataan kotor (logos sapros) $)^{71}$ keluar dari mulutmu (4:29). Jadi maksud Paulus di sini adalah janganlah ada kata, pernyataan, atau percakapan yang busuk, buruk, atau tidak baik keluar dari mulutmu, sebab kata-kata demikian adalah dosa yang harus dibuang, tetapi pakailah logos agatos ${ }^{72}$ perkataan yang baik. Kata

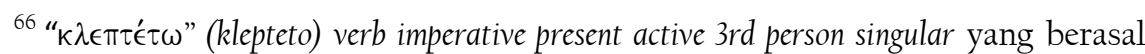
dari kata $\kappa \lambda \epsilon \epsilon \tau \omega$ (klepto) yang berarti steal (mencuri) (BMG Morphology, Word Analysis, s.v.

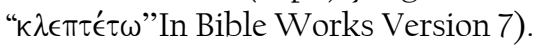

${ }^{67} \mu \hat{\alpha} \lambda \lambda \mathrm{o \nu}$ (mallon) adverb from $\mu \hat{\alpha} \lambda \lambda \mathrm{ov}$ (mallon) yang berarti more, better (lebih baik) (BMG Morphology, Word Analysis, s.v. " $\mu \hat{\alpha} \lambda \lambda \mathrm{\nu} \nu ”$ In Bible Works Version 7.

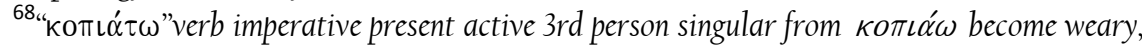
tired, work hard, toil, strive, struggle (berjerih lelah atau bekerja keras, berjuang) (BMG

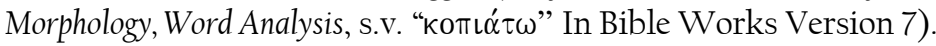

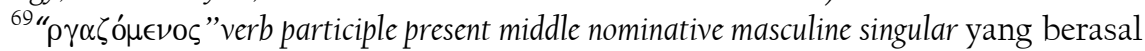

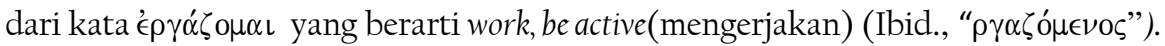

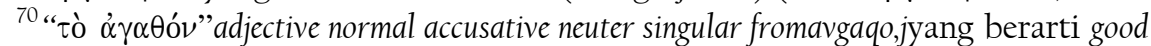
(baik) yaitu pekerjaan yang baik. Kata ini biasanya dihubungkan dengan ergon dan diterjemahkan dengan "pekerjaan yang baik" (LAI), "barang yang halal" (Schlier), "barang duniawi," "barang ethis" (a.l. Haupt, Kloper, Scott) (J. L. Ch. Abineno, Tafsiran Alkitab Surat Efesus (Jakarta: BPK Gunung Mulia, 2009), 161).

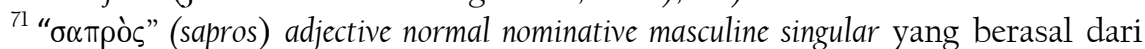

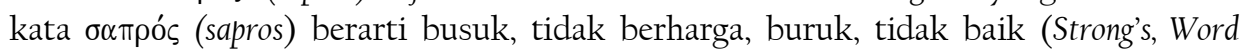
Analysis, s.v. "unwholesome" In Bible Works Version 7).

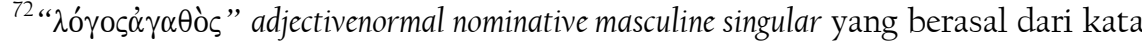

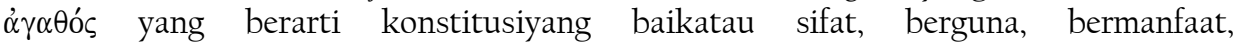
baik,menyenangkan, gembira, bahagia, sangat baik, berbeda, tegak lurus, terhormat.

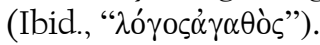


logos agatos juga (logos kalos, bdg. Ayub 7:1; 12:23; Luk.6:43; 13:48). Yang dimaksudkan di sini dengan perkataan yang baik adalah perkataan yang

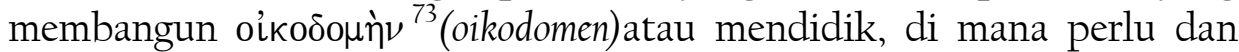
bukan mengeluarkan perkataan yang kotor yang dapat merusak, supaya memberikan faedah atau berkat $\mathrm{ca}$ rin $^{74}$ (karin) Allah kepada orang yang mendengarkan. Dalam nasihat ini Paulus mengingat akan perkataanperkataan kotor (busuk, buruk), yang banyak dipakai oleh orang-orang kafir dan sayang sekali juga dipakai oleh anggota-anggota jemaat. ${ }^{75}$

\section{Jangan Mendukakan Roh Kudus (4:30)}

Selanjutnya Paulus menasihatkan kepada jemaat Efesus supaya mereka "jangan mendukakan Roh Kudus (4:30)." "Mendukakan" di sini $\lambda$ U $\epsilon i \tau \epsilon \in$ (lupeite) ${ }^{76}$ yang berarti grieve, pain, to make sorrowful (mendukakan, menyakiti, atau membuat sedih). Sebenarnya di sini Paulus memberikan suatu kesimpulan bahwa semua perbuatan-perbuatan negatif dalam ayat-ayat sebelumnya yang telah diuraikan dan perbuatan di dalam (ayat 31) yaitu kepahitan, kegeraman, pertikaian serta fitnah merupakan perbuatan yang dapat mendukakan Roh Kudus. Di sini Paulus menggunakan bentuk imperative present di mana ia ingin memberikan nasihat yang bersifat perintah supaya jemaat menghentikan kebiasaankebiasaan atau perbuatan-perbuatan yang tidak baik yang sebenarnya adalah mendukakan atau menyakiti Roh Kudus.

Sebagai penjelasan tentang nasihat di atas yaitu supaya mereka (jemaat Efesus) "janganlah mendukakan Roh Kudus Allah, Paulus menambahkan "yang telah memeteraikan kamu menjelang hari penyelamatan." Maksud pernyataan ini adalah bahwa mereka yang telah belajar mengenal Kristus dan telah menjadi anggota tubuh-Nya, mengenal juga Roh Kudus. Roh Kuduslah yang telah mencekau mereka dan menetapkan mereka untuk masa depan Tuhan atau kedatangan Kristus yang kedua kali. Sebagai milik Kristus, merekalah meterai-Nya

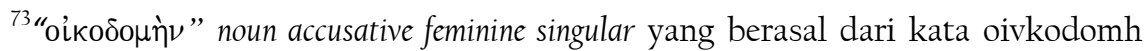
yang berarti building, edifice, In the sense edifying, edification, building up (bangunan,dalam

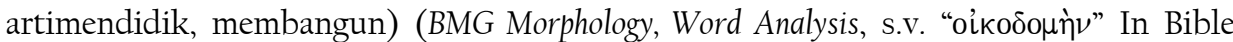
Works Version 7).

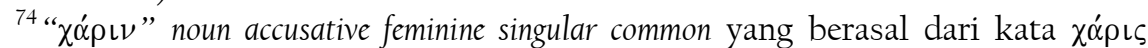
kasih karunia,kebaikan,berkat, keagungan (BMG Morphology, Word Analysis, s.v. " $\chi \alpha ́ \rho \iota \nu "$ In Bible Works Version 7). 2009), 162

${ }^{75}$ J. L. Ch. Abineno, Tafsiran Alkitab Surat Efesus (Jakarta: BPK Gunung Mulia,

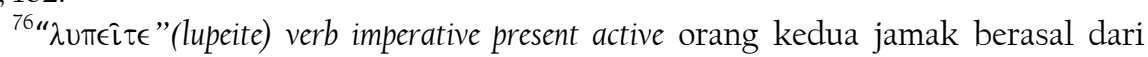
kata $\lambda \cup \pi^{\prime} \in \omega$ yang berarti mendukakan, menyakiti, atau membuat sedih (BMG

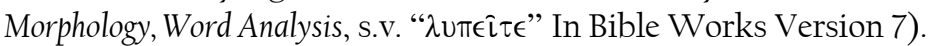


Ł $\sigma \phi \rho \alpha \gamma i ́ \sigma \theta \eta \tau \epsilon^{77}$ (esphragistete) yang berarti provide with a seal (memeteraikan, mencap, mengokohkan). Maksudnya adalah Roh Kuduslah yang akan mengokohkan mereka menjelang penyelamatan Kristus. ${ }^{78}$ Billy Garaham menambahkan bahwa peranan Roh Kudus adalah menerangi pikiran orang percaya, Roh Kudus tinggal di dalam tubuh orang percaya, Roh Kudus menghibur (Kis. 9:31), memimpin (Yoh. 16:13), menyucikan (Roma 15:16), membantu dalam kelemahan (Roma 8:26), dan Roh Kudus menyertai kehidupan orang percaya. ${ }^{79}$

\section{Menanggalkan Perbuatan Lama (4:31)}

Selanjutanya sebagai klimaks atau konklusi (kesimpulan) dari nasihat Paulus, ia berkata, "segala kepahitan $\pi \iota \kappa \rho i ́ \alpha$ (pikria) ${ }^{80}$ kegeraman

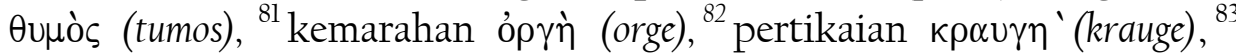

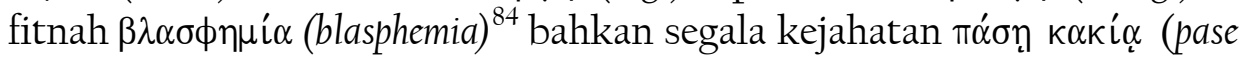
kakia), ${ }^{85}$ tanpa terkecuali bahwa semua bentuk kejahatan harus mereka

77 “є $\sigma \phi \rho \alpha \gamma i \sigma \theta \eta \tau \epsilon$ ” verb indicative aorist passive 2nd person plural berasal dari kata

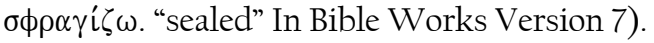
2009), 165 .

J. L. Ch. Abineno, Tafsiran Alkitab Surat Efesus (Jakarta: BPK Gunung Mulia,

${ }^{79}$ Billy Graham, Roh Kudus: Kuasa Allah Dalam Hidup Anda (Bandung: Lembaga Lietratur Baptis, 1978), 49-5l.

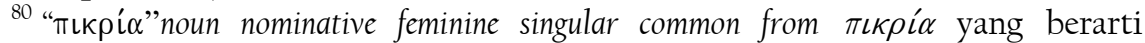
bitterness, animosity, anger (kepahitan, dendam, kemarahan) yaitu dari kepahitan, dendam

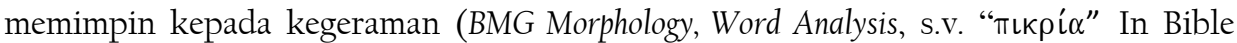
Works Version 7).

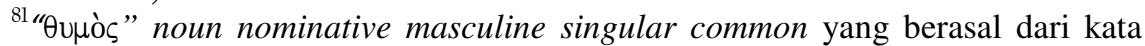

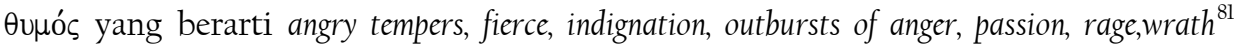
(emosi marah,sengit, kemarahan, ledakan kemarahan atau kemarahan yang hebat, gairah, kemarahan, murka) (BMG Morphology, Word Analysis, s.v. "Өupòc”" In Bible Works Version 7).

82 “o’pүฑ̀"(orge) noun nominative feminine singular yang berasal dariovrgh, (orge) yang berarti anger, wrath, indignation(marah, murka, kemarahan) (Ibid., "ópүì”).

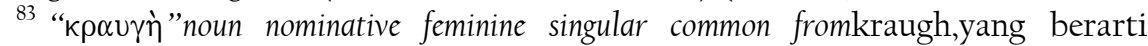
shouting, clamor, crying (krauge) yang berarti teriakan, tuntutan (menuntut), berteriak. Teriakan karena marah dan sebagai akibat timbul kegadulan, pertikaian dan sebagainya.

84 " $\beta \lambda \alpha \sigma \phi \eta \mu i ́ \alpha$ " noun nominative feminine singular common yang berasal dari kata $\beta \lambda \alpha \sigma \phi \eta \mu i \alpha$ yang berarti slander, abusive speech, blasphemies (fitnah, ucapan kasar, hujatan). Ternyata di dalam jemaat itu masih ada ucapan-ucapan kasar serta fitnahan (seperti penjelasan iblis sebagai pemfitnah yang bisa melakukan penipuan) dan juga terjadi hujatan di dalam jemaat.(Strong's, Word Analysis, s.v. "slander" In Bible Works Version 7).

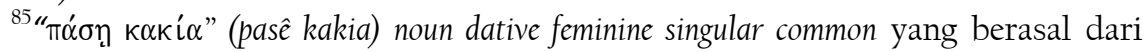

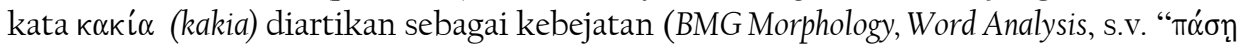

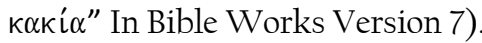


buang (bnd. 5:3) seperti percabulan, rupa-rupa kecemaran, dan keserakahan disebut saja pun jangan di antara kamu. Maksudnya adalah menyebutkan kejahatan saja pun adalah dosa, apalagi melakukannya (bnd. Efesus 5:3). Itulah sebabnya Paulus menasihatkan supaya semuanya itu dibuang (ditanggalkan) sebab semua itu adalah gambaran manusia lama (orang-orang kafir).

Namun, sebagai gantinya Paulus berkata "tetapi hendaklah kamu

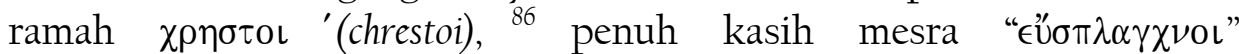
(eusplagchnoi) ${ }^{87}$ yaitu penuh dengan compassionate kasih yang tulus dan

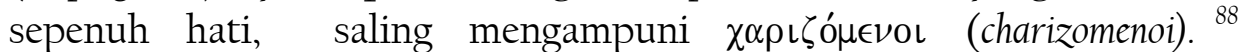
Melengkapi pernyataan ini, Paulus mengatakan bahwa "sebagaimana Allah di dalam Kristus telah mengampuni kamu." Maksudnya bahwa jemaat harus hidup saling mengampuni dengan murah hati, memberikan pengampunan satu dengan yang lain, bahkan dalam memaafkan orang lain harus disertai dengan kemurahan seperti Kristus dengan murah hati telah mengampuni segala dosa manusia. Pengampunan ini berdasar atas pengampunan yang Tuhan Allah berikan kepada mereka dalam Kristus. Dialah yang memungkinkan mereka untuk saling mengampuni, bahkan Dia pula yang menuntut supaya pengampunan yang demikian harus berlangsung di antara mereka.

Sebagai manusia baru di dalam Kristus yaitu memiliki kedudukan yang baru harus benar-benar menunjukkan kebaikan, kemurahan hati sebagai anggota tubuh Kristus (Efesus 4:15-16), penuh kasih mesra yaitu memiliki hati yang lemah lembut, penuh kasih, saling menaruh belas kasihan di antara jemaat, bahkan bermurah hati untuk memberikan pengampunan serta mampu memaafkan kesalahan orang lain sebagaimana Allah di dalam Kristus telah mengampuni segala dosa dan pelanggaran manusia.

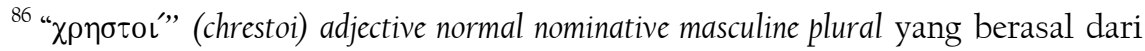

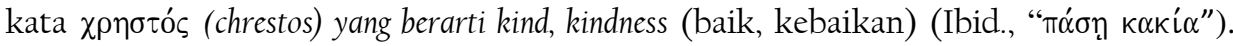
(J. L. Ch. Abineno, Tafsiran Alkitab Surat Efesus (Jakarta: BPK Gunung Mulia, 2009), 166).

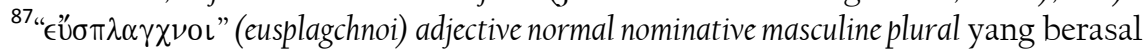

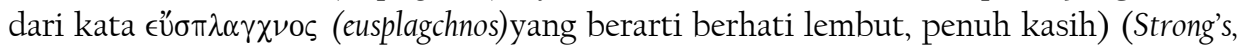
Word Analysis, s.v. "tenderhearted" In Bible Works Version 7).

${ }^{88}$ " $\chi \alpha \rho \iota \zeta o ́ \mu \epsilon \nu o \iota "$ (charizomenoi) verb participle present middle nominative masculine plural from $\chi \alpha \rho i \zeta o \mu \alpha \iota$ (charizomai) yang berarti menunjukkan kemurahan, memberikan secara bebas kemurahan atau pengampunan, dan murah hati memaafkan (Strong's, Word Analysis, s.v. "forgiven" In Bible Works Version 7). 2009), 167.

${ }^{89}$ J. L. Ch. Abineno, Tafsiran Alkitab Surat Efesus (Jakarta: BPK Gunung Mulia, 


\section{IMPLEMENTASI MANUSIA BARU DALAM KEHIDUPAN ORANG PERCAYA}

\section{Menanggalkan Manusia Lama}

Satu hal yang perlu disadari oleh orang Kristen bahwa di luar Kristus tidak ada pengharapan dan keselamatan, tetapi justru akan menempuh kebinasaan kekal (Efesus 4:20). Manusia lama yaitu manusia yang menindas kebenaran dengan kelaliman (Roma 1:18), yang tidak percaya kepada Allah, bahkan mereka menolak untuk mengakui Allah yang telah mewahyukan diri-Nya melalui ciptaan, ${ }^{90}$ mereka berjalan berdasarkan pengertian mereka, pikiran mereka sia-sia, memiliki pengertian yang gelap, jauh dari hidup persekutuan dengan Allah, hati mereka bodoh, degil, dan tumpul sehingga mereka mengerjakan dengan serakah segala macam kecemaran.

Menjadi manusia baru di dalam Kristus, orang percaya harus membuang atau menanggalkan perbuatan-perbuatan yang tidak berkenan kepada Allah seperti dusta, perkataan yang kotor, kemarahan, kepahitan, dendam, kebiasaan malas, dan mencuri. Perbuatan-perbuatan tersebut harus digantikan dengan kejujuran, perkataan yang baik dan membangun, kelemahlembutan, pengampunan, kasih mesra, serta tidak hidup bermalas-malasan tetapi bekerja keras.

\section{Mengenakan Manusia Baru di Dalam Kristus}

Mati dan bangkit bersama Kristus berarti manusia lama kita telah disalibkan dengan-Nya, dan berada dalam Roh mencakup pengenaan manusia baru atau manusia rohani (I Korintus 2:14). Mengenakan manusia baru di dalam Kristus berarti dipersatukan dengan Kristus. ${ }^{91}$ Di dalam Kristus berarti orang-orang yang dipisahkan dari dosa dan kegelapan serta hidup bagi Allah dan disebut sebagai orang-orang yang hidup di dalam Kristus. ${ }^{92}$ Hal ini perlu disadari bahwa sebagai orang percaya yang telah menerima Kristus sebagai Tuhan dan juruselamat harus benar-benar meninggalkan manusia lama yang penuh dengan dosa dan kebinasaan, lalu megenakan manusia baru di dalam Kristus yang telah diciptakan menurut kehendak Allah di dalam kebenaran dan kekudusan yang sesungguhnya. Secara eksplisit menerima Kristus berarti dipersatukan dengan-Nya dan hidup di dalam Dia dengan suatu ketaatan yang penuh kepada Dia serta hidup memuliakan-Nya.

\footnotetext{
${ }^{90}$ Richart L. Pratt Jr., Menaklukkan Segala Pikiran Kepada Kristus (Malang: Seminari Alkitab Asia Tenggara, 2000), 43.

${ }^{91}$ Sinclair B. Ferguson, Kehidupan Kristen: Sebuah Pengantar Doktrinal (Surabaya: Momentum, 2007), 137.

${ }^{92}$ Ibid., 138.
} 
Berikut ini ada beberapa ciri menjadi manusia baru di dalam Kristus yang perlu dimiliki dan dilakukan oleh orang percaya pada masa kini yaitu:

\section{Pertobatan}

Put off the old $\operatorname{man}^{93}$ (tanggalkan manusia lama). Paulus berkata bahwa "tetapi kamu bukan demikian, kamu telah belajar mengenal Kristus, karena kamu telah mendengar tentang Dia dan menerima pengajaran di dalam Dia menurut kebenaran yang nyata di dalam Yesus, yaitu bahwa kamu, berhubung dengan kehidupan kamu yang dahulu, harus menanggalkan manusia lama, yang menemui kebinasaannya oleh nafsunya yang menyesatkan." Penekanan Paulus ini sangat jelas bahwa ada suatu sikap yang harus dimiliki oleh setiap orang percaya yaitu bahwa untuk mengenakan manusia baru harus menanggalkan semua yang lama. Pertobatan adalah esensi dasar untuk mengenakan manusia baru. Warren Wiersbe berkata bahwa pertobatan adalah suatu krisis yang menuju kepada suatu proses. ${ }^{94}$

Mengenakan manusia baru di dalam Kristus harus terlebih dahulu menanggalkan yang lama. Hal tersebut dimulai dengan pertobatan, di mana orang percaya berketetapan berbalik arah yaitu menanggalkan yang lama dan mengenakan yang baru.

\section{Beriman Kepada Yesus Kristus}

Iman adalah sebagai modus eksistensi dari hidup baru. ${ }^{95}$ Beriman kepada Yesus berarti memasuki suatu kehidupan yang baru di dalam manusia baru yang telah diciptakan oleh Allah di dalam Yesus Kristus (Efesus 4:20-24). Beriman kepada Yesus Kristus adalah satu-satunya cara menerima manusia baru yang telah diciptakan oleh Allah. Ruth Paxson mengungkapkan dalam bukunya "The Wealth Walk and Warfare of the Christian" bahwa dengan tindakan kedaulatan Tuhan "manusia baru" telah dibuat. Oleh anugerah Tuhan orang-orang berdosa yang percaya itu dipercepat dan dibangkitkan bersama-sama dengan Kristus. Dalam kebangkitan tersebut Allah menciptakan "manusia baru" dan membuka jalan bagi dia untuk berjalan dalam kehidupan yang baru. $^{96}$

\footnotetext{
${ }^{93}$ Ruth Paxson, The Wealth Walk and Warfare of the Christian (USA: Fleming H. Revell Company Old Tappan, New Jersey, n.d), 107.

${ }^{94}$ Warren W. Wiersbe, Kaya di dalam Kristus (Bandung: Yayasan Kalam Hidup, 2001), 105.

${ }^{95}$ Herman Ridderbos, Paulus Pemikitan Utama Teologinya (Surabaya: Momentum, 2010), 241.

${ }^{96}$ Ruth Paxson, The Wealth Walk and Warfare of the Christian (USA: Fleming H. Revell Company Old Tappan, New Jersey, n.d), 110-111.
} 


\section{Menyerahkan Segala Pikiran Kepada Kristus}

Mengenakan manusia baru di dalam Kristus dimulai dengan pertobatan yaitu meninggalkan yang lama dan beriman kepada Yesus Kristus. Kedua hal tersebut tidak dapat dipisahkan untuk dapat menerima kehidupan yang baru di dalam Kristus. Namun, ada hal lain yang tidak dapat disepelekan oleh orang percaya yaitu menyerahkan segala pikiran kepada Kristus. Firman Allah membaharui pikiran orang percaya pada waktu menyerahkan segala sesuatu kepada-Nya (Roma 12:1-2). "Kuduskanlah mereka dalam kebenaran, Firman-Mu adalah kebenaran (Yohanes 17:17). Pada waktu pikiran orang percaya memahami kebenaran Firman Allah, maka pikiran itu akan dibaharui dan diubahkan oleh Firman Allah. ${ }^{97}$ Seperti yang dikatakan oleh Paulus bahwa ketika hidup di dalam perseketuan dengan Allah maka orang percaya akan dibaharui di dalam roh dan pikiran (Efesus 4:20,23). Di dalam mengenakan manusia baru di dalam Kristus setiap orang percaya harus memiliki penyerahan total kepada Allah untuk dibaharui secara terus menerus yang menuju kepada hidup yang diubahkan.

\section{Manusia Baru di Dalam Kristus Memiliki Kedudukan yang Baru}

Di dalam Efesus 2:2 mengatakan bahwa keadaan manusia lama adalah manusia taat kepada iblis (2:2), manusia di bawah kuasa hawa nafsu daging (Efesus 2:3), manusia mengalami murka Allah atau penghukuman Allah (Efesus 2:3), tetapi orang yang telah menerima Yesus Kristus menerima kedudukan yang baru di dalam Kristus, diperdamaikan dengan Allah (Roma 5:1), menerima kasih karunia (Roma 5:2), dibenarkan oleh Allah (Roma 4:25; 5:9; 5:18), menjadi anak-anak Allah. ${ }^{98}$ Seperti yang dikatakan oleh Richard bahwa pada saat kita diselamatkan dari dosa-dosa, manusia tidak hanya dilahirkan baru secara pribadi; melainkan manusia memasuki suatu ruang lingkup keberadaan yang baru (ciptaan baru) ${ }^{99}$ Oleh sebab itu, sebagai orang percaya yang telah menerima kasih karunia dan menjadi anak-anak Allah harus hidup sesuai dengan panggilan itu (Efesus 4:1) yaitu kedudukan yang baru di dalam Kristus. Paulus mengatakan di dalam Efesus 4:24 bahwa manusia baru itu telah diciptakan menurut kehendak Allah di dalam kekudusan dan kebenaran yang sesungguhnya.

\footnotetext{
${ }^{97}$ Ibid., 105-106.

${ }^{98}$ Ibid., 123.

${ }^{99}$ Richard L. Pratt Jr, Menaklukkan Segala Pikiran Kepada Kristus (Malang: Seminari Alkitab Asia Tenggara, 2003), 57.
} 


\section{Pikiran yang Terus Diperbaharui}

Orang percaya perlu menyadari bahwa dunia menawarkan berbagai kenikmatan yang membawa manusia kepada suatu kehancuran yaitu dosa. Oleh sebab itu, orang percaya harus memiliki sikap penyerahan diri kepada Allah sehingga pikirannya dikendalikan oleh Allah. Maksudnya adalah orang percaya di dalam Yesus Kristus diperbaharui menurut sifat mereka yang semula sebagai manusia yang diciptakan menurut gambar Allah. ${ }^{100}$

\section{Tidak Menjadi Senjata Kelaliman}

Menjadi manusia baru di dalam Yesus Kristus berarti berarti menerima penebusan dosa, bukan karena perbuatan baik manusia, tetapi karena perbuatan Tuhan Yesus. Menjadi manusia beru di dalam Yesus berarti telah mengambil bagian dalam kematian Tuhan Yesus sehingga dosa-dosanya telah dihapuskan, menerima kebangkitan Tuhan Yesus, manusia lamanya telah disalibkan, memandang dirinya telah mati bagi dosa dan hidup bagi Allah di dalam Yesus Kristus (Roma 6:11), dan tidak memberi dirinya menjadi senjata kelaliman (dosa), melainkan menyerahkan dirinya atau anggota tubuhnya untuk menjadi senjata kebenaran. ${ }^{101}$ Sebagai orang percaya pada masa kini perlu memahami dan mengenali dirinya bahwa sebagai manusia baru di dalam Kristus totalitas hidupnya harus memuliakan Allah dengan memberikan dirinya atau anggota-anggota tubuhnya untuk menjadi senjata kebenaran Allah dan hidup menjauhkan diri dari segala kenajisan dan perbuatanperbuatan dosa lainnya sehingga dengan demikian kehidupannya mampu menyatakan gambaran Allah (sifat Allah) yaitu kebenaran dan kekudusan Allah bagi dunia.

\section{Sikap Orang Percaya Terhadap Roh Kudus}

Paulus mengatakan bahwa Roh Kudus merupakan oknum yang sangat nyata baginya seperti halnya Yesus Kristus. Paulus menyadari pentingnya Roh Kudus dalam pelayanannya, gereja, dan kehidupan masing-masing orang percaya. ${ }^{102}$ Pemahaman tersebut juga seharusnya dimiliki oleh orang percaya pada masa kini, di mana perlu menyadari akan pentingnya Roh Kudus dalam kehidupan sehari-hari. Alkitab mengajarkan bahwa Roh Kudus adalah satu pribadi ${ }^{103}$ yang diutus oleh Allah (Kisah Para Rasul 1:8) untuk menghibur orang percaya, menyertai

\footnotetext{
${ }^{100}$ Richard L. Pratt Jr, 57.

${ }^{101}$ Chris Marantika, Kepercayaan dan Kehidupan Kristen (Yogyakarta: Sekolah Tinggi Teologia Injili Indonesia,1985), 179-180.

${ }^{102}$ Stanley M. Horton, Oknum Roh Kudus (Malang: Gandung Mas, 1976), 157.

${ }^{103}$ Billy Graham, Roh Kudus: Kuasal Allah Dalam Hidup Anda (Bandung: Lembaga Literatur Baptis, 1978), 15.
} 
orang percaya hingga hari penyelamatan yaitu kedatangan Yesus Kristus pada kali yang kedua (Efesus 4:30), menerangi pikiran orang percaya (I Kor 2:10), dan tinggal di dalam hidup orang percaya (I Kor 6:19).

Sehubungan dengan hal tersebut di atas, maka orang percaya perlu menyadari pentingnya Roh Kudus dalam kehidupan ini yang selalu menghibur, menyertai, bahkan menuntun dan membimbing orang percaya kepada jalan yang benar serta mengingatkan orang percaya supaya tidak melakukan suatu kejahatan di hadapan Tuhan. Oleh sebab itu sebagai manusia baru di dalam Kristus, janganlah mendukakan Roh Kudus Allah yang telah dimeteraikan bagi orang percaya menjelang hari penyelamatan. Mendukakan berarti melakukan perbuatan-perbuatan yang tidak berkenan kepada Allah atau yang tidak cocok dengan sifat Roh Kudus sehingga melukai hati-Nya. ${ }^{104}$ Roh Kudus penuh kasih seperti Kristus (Roma 15:30), dan Ia sangat mengasihi orang percaya yang telah memeteraikan mereka. Tetapi, ketika orang percaya melakukan perbuatan-perbuatan yang tidak baik (dosa), maka hal itu dapat mendukacitakan Roh Kudus. Dusta, kemarahan, mencuri, perkataan kotor, kepahitan, kegeraman, pertikaian, fitnah, dan segala kejahatan, adalah perbuatan-perbuatan yang mendukakan Roh Kudus. Oleh sebab itu, semuanya itu harus dibuang atau ditanggalkan dari kehidupan orang percaya.

\section{Sikap Orang Percaya Terhadap Sesama}

Satu hal yang esensial dalam kehidupan kekristenan adalah bagaimana menyatakan karakter Kristus dalam praktika kehidupan sehari-hari. Karakter Kristus tersebut dapat dinyatakan terhadap Allah dan terhadap sesama. Sebagai manusia baru di dalam Kristus, tentunya ada tuntutan-tuntutan sikap atau perbuatan yang harus dimiliki dan dilakukan oleh setiap orang percaya.

Hal pertama yang perlu dilakukan oleh orang percaya adalah penuh kasih mesra terhadap sesama yaitu penuh dengan belas kasihan, kasih yang tulus yang dicurahkan dari hati. Mengasihi orang-orang harus dilakukan seperti Tuhan mengasihi manusia. ${ }^{105}$ Paul Caram mengatakan bahwa kasih adalah kekuatan untuk mendahulukan orang lain dan kekuatan untuk tidak mementingkan diri sendiri, dan menanggung segala sesuatu. ${ }^{106}$

Baik dalam kehidupan keluarga, jemaat, maupun dalam kehidupan bermasyarakat sikap mendahulukan orang lain dengan tidak mementingkan diri sendiri harus mampu diwujudkan oleh setiap orang

\footnotetext{
${ }^{104}$ Billy Graham, 199-200.

${ }^{105}$ Paul G. Caram, Kekristenan Sejati (Jakarta: Voice of Hope, 2004), 108.

${ }^{106}$ Ibid., 40.
} 
percaya di dalam kehidupan sehari-hari. Dengan demikian karakter Kristus akan semakin nampak dalam kehidupan Kristen dan Kristus dipermuliakan melalui kehidupan orang percaya. Kasih yang berasal dari Allah harus benar-benar tertanam baik dalam kehidupan orang percaya supaya dengan demikian kasih itu juga dapat dinyatakan kepada orang lain. Selain kasih mesra, orang percaya juga harus hidup di dalam pengampunan sama seperti Kristus telah mengampuni semua orang berdosa. Teladan pengampunan dapat dilihat kepada Allah yang telah mengampuni manusia. Pengampunan adalah perbuatan Allah yang timbul dari rahmat-Nya. ${ }^{107}$ Seharusnya semua manusia berdosa harus mengalami murka Allah yaitu penghukuman Allah karena segala kafasikan dan kelaliman manusia yaitu segala kejahatan dan pemberontakan manusia terhadap Allah (Roma 1:18), tetapi karena Allah yang penuh kasih dan rahmat sehingga manusia tidak mengalami penghukuman itu dan Allah menunjukkan kasih dan keadilan-Nya di dalam Yesus Kristus untuk menebus segala dosa dan pelanggaran manusia (I Petrus 2:24). Karakter kasih dan pengampunan seharusnya juga dimiliki oleh orang percaya supaya dapat menyatakan pengampunan terhadap sesama. Allah sangat menentang ketidakadilan, namun sangat mungkin Ia tertarik terhadap reaksi yaitu kekuatan orang percaya memberikan tanggapan yang benar terhadap orang-orang yang memberikan perilaku yang dapat menimbulkan sakit hati.

${ }^{107}$ G. C. Van Niftrik dan B. J. Boland, Dogmatika Masa Kini (Jakarta: BPK Gunung Mulia, 1984), 476. 


\section{PENUTUP}

\section{Kesimpulan}

Berdasarkan hasil uraian penulis dalam karya ilmiah ini tentang konsep manusia baru berdasarkan perspektif Paulus dalam Efesus 4:1732 dan implementasinya dalam kehidupan orang percaya, maka penulis dapat menarik beberapa kesimpulan sebagai berikut:

Pertama, manusia lama adalah manusia yang berjalan berdasarkan pengertiannya sendiri, tidak mengenal Allah, memiliki pikiran yang siasia, pengertiannya digelapkan, jauh dari hidup persekutuan dengan Allah, memiliki hati yang degil, hati tumpul, sehingga menyerahkan dirinya kepada hawa nafsu dan mengerjakan dengan serakah segala macam kecemaran.

Kedua, berdasarkan konteks yang penulis bahas dalam Surat Efesus 4:17-32, manusia baru adalah manusia yang telah diciptakan menurut kehendak Allah di dalam kebenaran dan kekudusan, di mana orangorang yang percaya kepada Kristus memiliki kedudukan baru yaitu dari kebinasaan dipindahkan kepada hidup yang kekal dan manusia yang terus diperbaharui serta dipersatukan dengan Kristus.

Ketiga, sebagai manusia baru di dalam Kristus, orang percaya tidak lagi menjadi senjata-senjata kelaliman tetapi sebaliknya menjadi senjatasenjata kebenaran dan hidup memuliakan Allah. 


\section{KEPUSTAKAAN}

Alkitab

Alkitab. Jakarta: Lembaga Alkitab Indonesia, 2008.

Alkitab Penuntun Hidup Berkelimpahan. Jakarta: Lembaga Alkitab Indonesia. 1957.

Sutanto, Hasan. Perjanjian Baru Interlinear Yunani-Indonesia dan Konkordansi Perjanjian Baru Jilid I \&II. Jakarta: Lembaga Alkitab Indonesia, 2010.

Bible Works Version 7.

Buku-Buku

Abineno, J.L. Ch. Tafsiran Alkitab Surat Efesus, Jakarta: BPK Gunung Mulia, 2009.

Baxter, J. Sidlow. Menggali Isi Alkitab:Roma Sampai dengan Wahyu. Jakarta: Yayasan Komunikasi Bina Kasih, 2011

Barclay, William. Pemahaman Alkitab Setiap Hari Galatia Efesus. Jakarta: BPK Gunung Mulia, 1986.

Caram, Paul G. Kekristenan Sejati. Jakarta: Voice of Hope, 2004.

Ferguson, Sinclair. Kehidupan Kekristenan Sebuah Pengantar Doktrinal. Surabaya: Momentum, 2007.

Graham, Billy. Roh Kudus: Kuasa Allah Dalam Hidup Anda, Bandung: Lembaga Literatur Baptis, 1978.

Groenen C. OFM. Pengantar ke Dalam Perjanjian Baru.Yogyakarta: Kanisius, 1984.

Harlow, R.E. Ephesians in the Beloved, Canada: Everyday Publications INC, 1979 .

Horton, Stanley M. Oknum Roh Kudus. Malang: Gandung Mas, 1976.

Marantika, Chris. Kepercayaan dan Kehidupan Kristen. Yogyakarta: Sekolah Tinggi Teologia Injili Indonesia, 1996.

Paxon, Ruth. The Wealth Walk and Warfare of the Christian, United Stated of Amerika: Fleming H. Revell Company. n. d.

Niftrik, G. C. Van dan B. J. Boland, Dogmatika Masa Kini. Jakarta: BPK Gunung Mulia, 1984.

Pratt, Richard L. Menaklukkan Segala Pikiran Kepada Kristus. Malang: Seminar Alkitab Asia Tenggara, 2003.

Ridderbos, Herman. Paulus: Pemikiran Utama Teologinya. Surabaya: Momentum, 2008.

Wiersbe, Warren W. Kaya di Dalam Kristus, Bandung: Yayasan Kalam Hidup, 2001. 